\title{
プレファブ土壁の静的・動的試験による耐力特性評価と 超音波測定を用いた損傷推定 \\ EVALUATION OF STRUCTURAL PERFORMANCE OF PREFABRICATED MUD-SHEAR WALL USING STATIC AND DYNAMIC TESTS AND DAMAGE ESTIMATION BY ULTRASONIC MEASUREMENT METHOD
}

\author{
脇田健裕*1, 北守顕久*2, 鄭 基 浩*3, 森 拓 郎*4 \\ 小松幸平*5, 片岡靖夫*6, 曽田五月也*7, 宋 成 涁*8 \\ Takehiro WAKITA, Akihisa KITAMORI, Kiho JUNG, \\ Takuro MORI, Kohei KOMATSU, Yasuo KATAOKA, \\ Satsuya SODA and Sungbin SONG
}

\begin{abstract}
Prefabricated mud-shear wall is a mud-shear wall in a compact modular size manufactured in factory work. At construction sites it is constructed simply by being fitted into a wooden frame. It keeps the quality stable even if there is no skilled craftsmen, and it significantly shortens the construction period. In this paper we evaluated structural performance of prefabricated mud-shear wall conducted using static loading test and dynamic shaking table test. It is confirmed that the shear wall has a simple structural mechanism that depends on the single unit, and so its structural performance can be analyzed by a simple model. It is also confirmed that ultrasonic measurement method applied to the prefabricated mud-shear wall is effective for damage evaluation estimation.
\end{abstract}

Keywords : Prefabricated Mud-shear Wall, Ultrasonic measurement method, Time history response analysis, Mechanical model based on extended normalized characteristic loop, Shaking table test プレファブ土壁, 超音波測定, 時刻歴応答解析, 拡張 NCL モデル, 振動台実験

\section{1. はじめに}

プレファブ土壁は筆者らが提案した自然素材活用型住宅の主要構 造要素の一つである ${ }^{112)}$ 。プレファブ土壁は一定寸法にモジュール 化した小型土壁 (プレファブ土壁単体ユニットと呼ぶ)を予め工場作 業にて製作し、建築現場においては木枠へのはめ込み作業のみを行 う構法である (図 1)。伝統的な木造建築で用いられてきた湿式構法 の土塗り壁は、建築現場で壁を造り上げて完成するために、熟練し た職人技術と、3〜4 ケ月という長い期間を要するのに対し、本構法 では現場作業を大幅に簡素化し短工期化することが可能である。

また、土壁に耐力壁としての構造性能を期待する場合、引張、せ 几断強度に比して、圧縮強度の高い壁土の特性を考えると、縦横比 が 1：1 に近くかつ対角線長さの短いプレファブ土壁の単体ユニッ 卜は伝統的土壁に比べ、せん断力に対する対角線圧縮抵抗力をより 有効に利用することが可能であると考えられる。

伝統的土壁の耐荷機構は村上ら ${ }^{3)}$ の研究で示されているように、
間渡し竹によるダボ的抵抗、隅角部の壁土の圧縮力による抵抗、土 壁内部の貫のこじりによる抵抗、貫表面と接触する土との間の付着 力による抵抗等が複合的に組み合わされており、その分担割合は壁

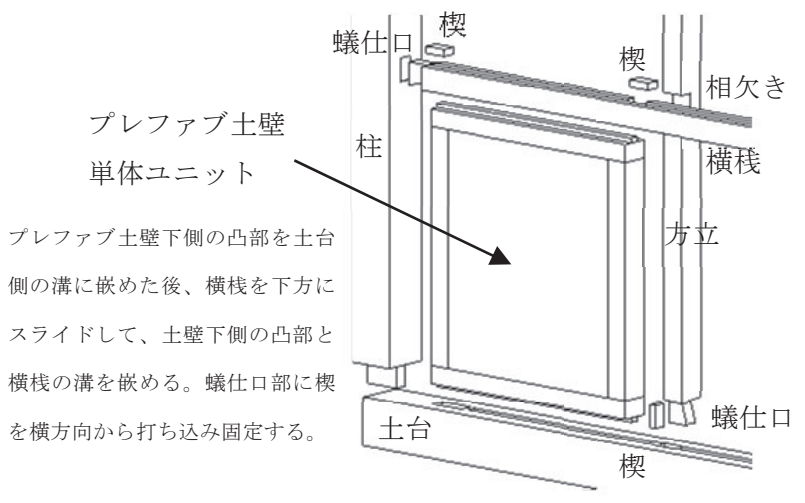

図 1 プレファブ土壁構成図

\footnotetext{
*1 中部大学工学部建築学科 助教 $\cdot$ 修士 (工学)

*2 京都大学生存圈研究所 助教・博士 (農学)

*3 静岡大学教育学部 准教授・博士 (農学)

*4 京都大学生存圈研究所 助教・博士 (工学)

*5 京都大学生存圈研究所 教授・博士 (農学)

*6 中部大学工学部建築学科 客員教授・博士 (工学)

*7 早稲田大学創造理工学部建築学科 教授 - 博士 (工学)

*8 早稲田大学理工学研究所 招聘研究員 ·修士 (工学)
}

Assistant Prof., Dept. of Architecture, Chubu Univ., M. Eng.

Assistant Prof., R.I.S.H, Kyoto Univ., Dr. Agr.

Assoc. Prof., Faculty of Education, Shizuoka Univ., Dr. Agr.

Assistant Prof., R.I.S.H, Kyoto Univ., Dr. Eng.

Prof., R.I.S.H, Kyoto Univ., Dr. Agr.

Visiting Prof., Dept. of Architecture, Chubu Univ., Dr. Eng.

Prof., Dept. of Architecture, Waseda Univ., Dr. Eng.

Visiting Researcher, Research Inst. for Sci. and Eng., Waseda Univ., M. Eng. 
の各種寸法や開口形状の他、壁土の種類や施工者の技量によっても 大きく異なり、これらの仕様を踏まえて荷重一変位曲線全体を適切 にモデル化するのは非常に困難である。

山田ら ${ }^{4)}$ 、中尾ら ${ }^{5)}$ は数值解析により土塗壁の荷重一変位曲線を 予測する手法を提案しているが、これらの解析を行うためには、多 種類の抵抗要素のモデル化と、複雑な解析モデルの構築が必要とな る。

一方でプレファブ土壁の耐荷機構は単体ユニットの抵抗性能にほ ぼ依存するため、単体ユニットの復元力特性を把握し、そのモデル 化さえ行えば、これを組み合わせた形の異なった寸法や開口形状を 持つ壁の耐力特性は、比較的簡単な解析で正確に把握可能であると 考えられる。

本論ではプレファブ土壁の力学的特性を静的・動的加力試験によ り明らかにした上で、各種の開口形状を持つプレファブ土壁の耐力 特性を予測する解析手法を構築しその妥当性を検討する。また、静 的・動的加力試験における土壁内部の損傷状況の把握には、既報 ${ }^{6)}$ において提案した土壁の非破壊損傷評価手法である超音波伝播速度 測定を適用し、その実用性とプレファブ土壁耐力壁の破壊進行メカ ニズムについての検討をおこなう。

\section{2. 静的加力試験による耐力特性の比較}

\section{1 試験概要}

プレファブ土壁の基本的な耐力特性について静的加力試験を用い て検討を行う。試験体は図 2 に示すプレファブ土壁の単体ユニット (以下単体ユニット) と、図 3 に示寸単体ユニットを 12 体配置したプ レファブ土壁全面壁 (以下プレファブ土壁)、また比較用として図 4 に示寸伝統的構法の仕様で製作した土壁 (以下伝統的土壁) と、柱、 梁、土台のみ木造軸組みフレーム (以下木軸フレーム)の 4 体である。 単体ユニットは 4 周の木枠の内側に竹小舞を組み、その両面に荒 壁土 $(30 \mathrm{~mm}) 、$ 中叙り土 $(10 \mathrm{~mm}+10 \mathrm{~mm})$ を叙り付け乾燥し製作した。

プレファブ土壁の施工方法は、まず柱、梁、土台の軸組に方立、 横栈を差込み組み上げた上で、最下段に単体ユニットを 3 体配置す る。次に、単体ユニット直上の横栈を下方にスライドすることで、 単体ユニット上部の凸部を横栈の溝に差込み固定し、さらに横栈端 部の下げ蟻部の隙間に楔を打つ。この横栈の上に次の単体ユニット 3 体を配置し、固定することを繰り返し全面壁が完成する。なお、 自然素材活用型住宅 ${ }^{1)}$ の基本理念に則り、プレファブ土壁の組み上 げとユニットの固定には、釷や金物等の金属部材を一切使用せず全 て嵌合によるものとした。

伝統的土壁は一般的に施工される標準的な仕様で製作した。横貫 の端部は通し貫としないで柱内に収め、荒壁土 $(36 \mathrm{~mm}) 、$ 中塗り土 $(12 \mathrm{~mm}+12 \mathrm{~mm})$ を塗り付け乾燥させた。また、貫伏せをおこない貫と中 塗り土の付着性を向上させた。

試験体に使用した壁土は全て京都市伏見区大亀谷の土(深草土)で ある。表 1 に使用した壁土の配合比を示す。スサ混入後に、荒壁土 では 3 か月、中塗り土では 3 日間寝かして発酵させた上で塗り付け を行った。表 2 に試験に使用した壁土の圧縮試験結果を示す。試験 は技術解説書 ${ }^{7)}$ の壁土の圧縮試験方法に従い、厚 $80 \mathrm{~mm}$ で $120 \mathrm{~mm} \times$ $120 \mathrm{~mm}$ の大きさの試験体を用いて行った。荒壁土の圧縮強度が他産 地のものに比べて高いことが特徴的であり、技術解説書 ${ }^{7)}$ に示され
る值を大きく上回っている。

実験は図 5 に示寸ように各試験体の柱脚部分をホールダウン金物 とアンカーボルトにて鋼製土台と接合した上で、無載荷式の正負交 番繰返し加力にて行った。加力は正弦波を用いて、試験体の層間変 形角が $1 / 450 、 1 / 300 、 1 / 200 、 1 / 150 、 1 / 120 、 1 / 100 、 1 / 50 、 1 / 30 、$ 1/17. $5 \mathrm{rad}$ となる振幅で 3 回ずつ繰り返した。

\begin{tabular}{|c|c|c|} 
表 1 & \multicolumn{3}{|c|}{ 壁土の配合比 (体積) } \\
\hline & 荒壁土 & 中塗り土 \\
\hline 土 & 3 & 3 \\
\hline スサ & 1 & 1 \\
\hline 砂 & & 1 \\
\hline
\end{tabular}

表 2 壁土の最大圧縮強度

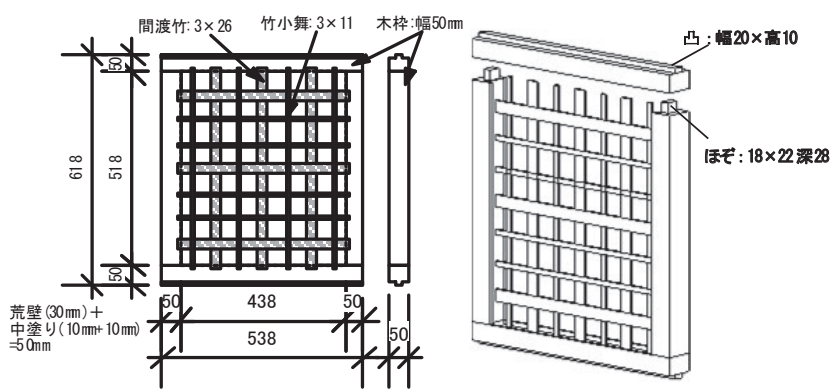

図 2 プレファブ土壁単体ユニット

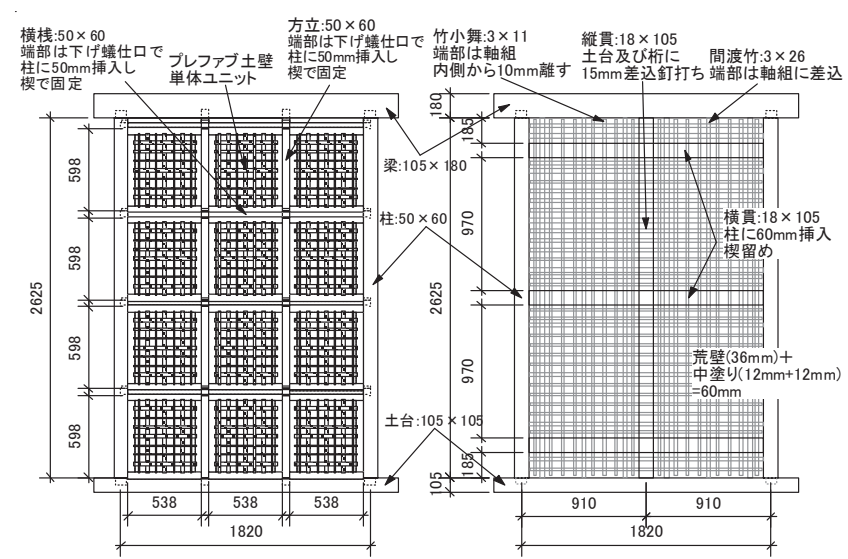

図 3 プレファブ土壁

図 4 伝統的土壁

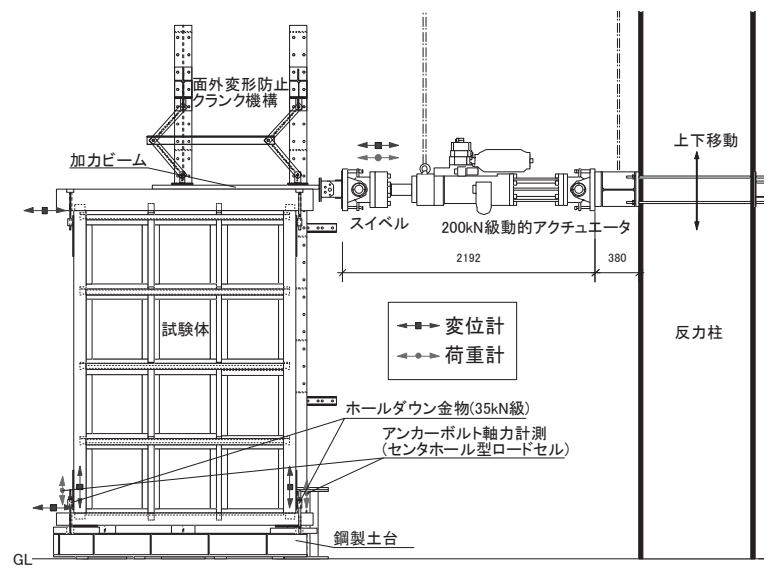

図 5 静的加力試験試験システム図

\section{2 荷重変形関係・包絡線による比較}

図 6 に各試験体の荷重変形関係を示す。単体ユニットとプレファ ブ土壁は共に伝統的土壁に比べ初期剛性が低く、終局変形角時 
(1/17. 5rad. ) に最大耐力に達するのに対し、伝統的土壁は 1/50rad. 加力時に最大耐力に達した後、緩やかに耐力低下している。表 3 は 各試験体の荷重変形関係のプラス側包絡線を用いて設計用特性值を 評価 ${ }^{8)}$ した結果である。プレファブ土壁と伝統的土壁は最大耐力で は同程度であるが、壁倍率では伝統的土壁の方が 2 倍以上高い值と なっている。この理由は初期剛性と塑性率が高い伝統的土壁の短期 許容せん断耐力值が降伏耐力值により決定するのに対し、初期剛性 と塑性率が低いプレファブ土壁では、1/120rad. 時の耐力值と $\mathrm{Pu}$ ・ (0.2/Ds) が極端に低い值となり、この值が短期許容せん断耐力值と なるためである。なお、プレファブ土壁の初期剛性が低い理由は、 単体ユニットと木軸フレーム間の滑りにより、小変形角時に壁土の 圧縮抵抗力を十分に伝達できなかったことによるものと考えられる。 なお、本試験では試験機の性能限界により 1/17. $5 \mathrm{rad}$. を終局変形角 とした。木造耐力壁の性能評価試験方法 ${ }^{8)}$ では終局変形角は 0.8Pmax 荷重低下時か $1 / 15 \mathrm{rad}$. のどちらかであり、これに従うとプレファブ 土壁の各耐力值及び塑性率等はより高い值になると推測されが、 1/120rad. 時の耐力值が低いままであるため、短期許容耐力值及び壁 倍率は大きくは変わらない。

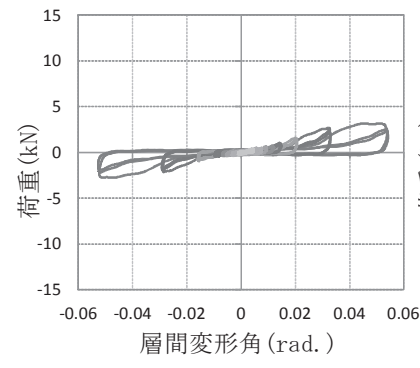

(a)プレファブ土壁単体ユニット

(c) 伝統的土壁

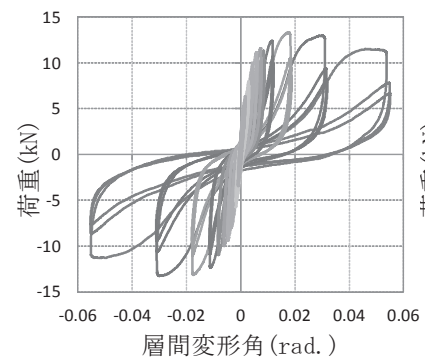

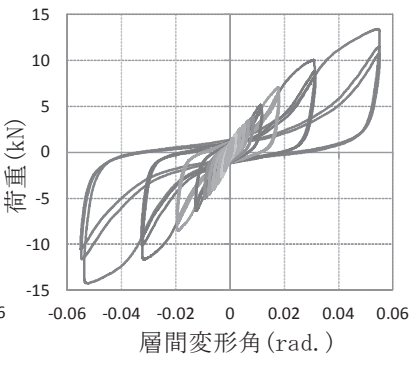

(b) プレファブ土壁

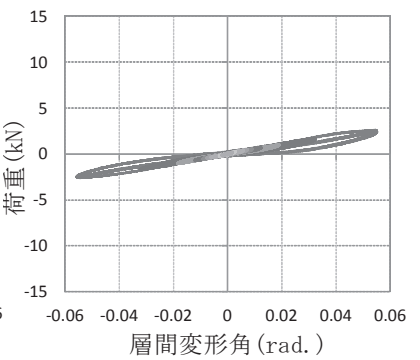

(d) 木軸フレーム
図 6 静的加力試験の荷重変形関係

表 3 包絡線による設計用特性值評価結果一覧

\begin{tabular}{|c|c|c|c|c|}
\hline 特性値 & |(a)プレ土単体 & (b)プレ土壁 & (c)伝統土壁 & (d)木軸 \\
\hline 最大耐力Pmax(kN) & 3.13 & 13.37 & 13.29 & 2.58 \\
\hline 最大耐力時変形角Rmax(rad) & 0.0510 & 0.0547 & 0.0177 & 0.054 \\
\hline 降伏耐力Py(kN) & 1.68 & 8.31 & 8.36 & 1.38 \\
\hline 降伏変形角Ry(rad) & 0.0229 & 0.0226 & 0.0034 & 0.0244 \\
\hline 終局耐力Pu(kN) & 3.05 & 12.15 & 12.40 & 2.48 \\
\hline 終局変形角Ru(rad) & 0.0536 & 0.0552 & 0.0539 & 0.0551 \\
\hline 降伏点変形角Rv(rad) & 0.0414 & 0.0330 & 0.0051 & 0.0439 \\
\hline 剛性(KN/rad) & 74 & 368 & 2426 & 56 \\
\hline 塑性率 $\mu$ & 1.30 & 1.67 & 10.55 & 1.26 \\
\hline 構造特性係数Ds & 0.79 & 0.65 & 0.22 & 0.81 \\
\hline $\mathrm{Pu} \cdot(0.2 / \mathrm{Ds})(\mathrm{kN})$ & 0.77 & 3.71 & 11.12 & 0.61 \\
\hline 2/3Pmax (kN) & 2.09 & 8.91 & 8.86 & 1.72 \\
\hline 1/120rad.時の耐力(kN) & 0.48 & 3.79 & 11.58 & 0.53 \\
\hline 短期許容せん断耐力(kN) & 0.48 & 3.71 & 8.36 & 0.53 \\
\hline 壁倍率 $(1 \mathrm{~m}$ 当たり) & & 1.0 & 2.3 & 0.1 \\
\hline
\end{tabular}

\section{3 剛性、減衰、保有エネルギーによる比較}

図 7 に各加力における等価剛性 Keq の推移を示す。小变形角時で はプレファブ土壁は伝統的土壁の $1 / 3$ 程度の剛性であるが、 $1 / 30 \mathrm{rad}$. 加力時にほぼ同等の剛性となる。図 8 は各加力の 1 サイクル目の加 カループから算出した等価粘性減衰定数 heq の変化を示す。プレフ アブ土壁の heq は、単体ユニットよりも低い值で推移している。こ れは、木枠接合部の摩擦やめり込久等の壁土以外の要素によるエネ ルギー吸収の影響が、全面壁と比べて相対的に大きいためであると 考えられる。また、小振幅時には伝統的土壁と比べプレファブ土壁 が高い值で推移しているが、剛性が同等となる $1 / 30 \mathrm{rad}$. 以降は伝統 的土壁の方が若干高くなっていることが分かる。

図 9、図 10 は各加力の包絡線から算出する保有エネルギー付䟿) の 変化について示す。損傷限界エネルギーの変化率において、伝統的 土壁は最大経験変形角が $1 / 200 \mathrm{rad}$.を境に大きく低下し最終的に約 10\%にまで落ちるのに対し、単体ユニット、プレファブ土壁は共にほ ぼ同じ傾向で、緩やかに低下しながら 60\%以上を維持していること が分かる。安全限界エネルギーについても、プレファブ土壁は伝統 的土壁に比べて高い值で推移している。繰り返しの加力に対する保 有エネルギーの低下が少ないことは、地震等の繰り返しの加力に対 しての応答低減に対しては有利であると考えられる。
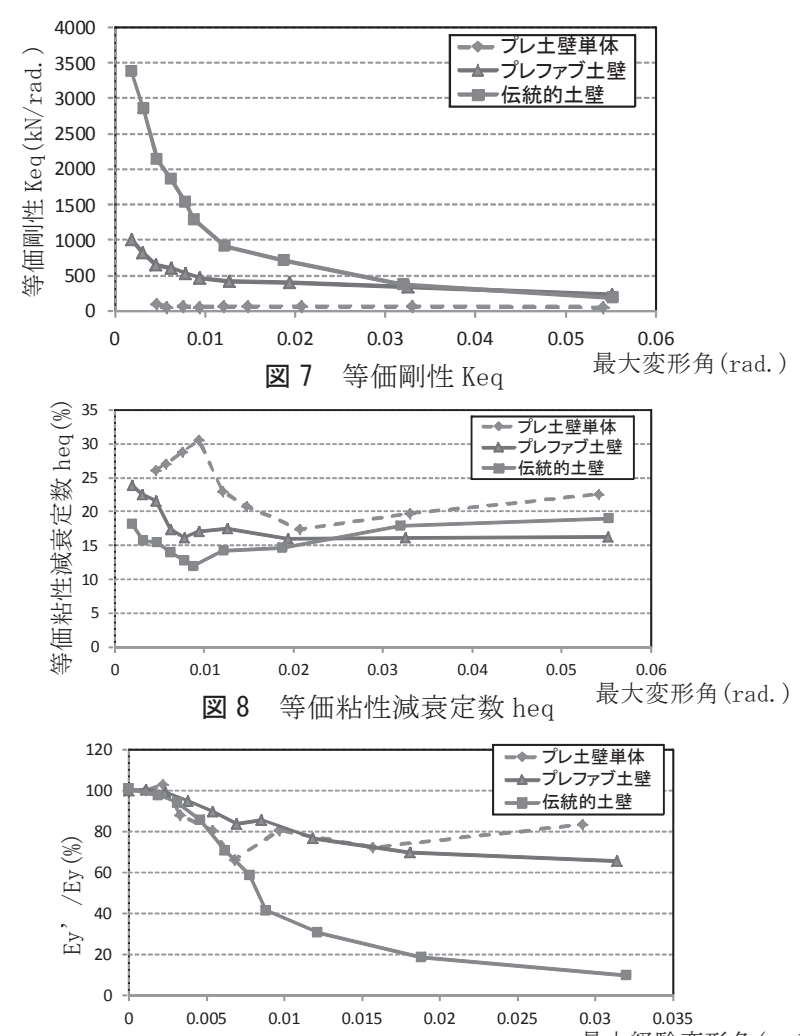

図 9 損傷限界エネルギーEy

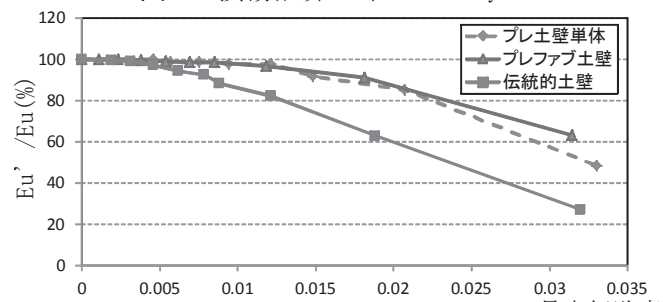

図 10 安全限界エネルギーEu 最大経験変形角 (rad.) 


\section{4 土壁表面のひび割れと破壊モードの考察}

図 11 に 1/17. 5 rad. 加力終了後のプレファブ土壁と伝統的土壁の 表面ひび割れ状況を示す。プレファブ土壁は各単体ユニットの隅角 部に多くのひび割れが見られる。プレファブ土壁のせん断耐力の発 現機構は、各ユニットの隅角部の壁土一の圧縮力による抵抗が支配 的であり、大変形時の破壊は壁土の圧縮強度に達するか、木枠材と 接触した隅角部近傍の竹小舞及び間渡竹が座屈し、壁土を厚み方向 に押し出す様に破壊したものと推察できる。

一方、伝統的土壁のひび割れは隅角部と横貫の近傍に集中し、ま た縦貫に沿っても発生している。伝統的土壁は隅角部の圧縮力によ る抵抗の他、貫の壁土へのこじりによる抵抗や、貫表面と接触する 壁土との間に発生する付着力、貫自体の曲げ抵抗と軸組への挿入部 のめり込み抵抗などが複合的に発生すると考えられ、損傷部位によ ってその破壊原因は異なる。

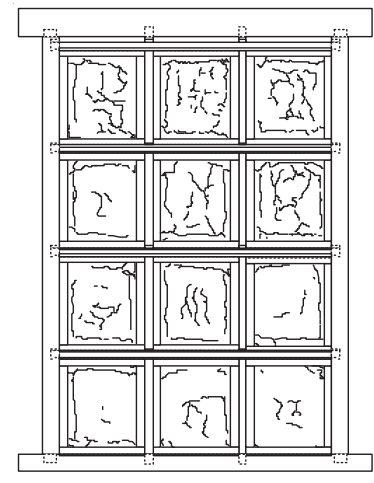

(a)プレファブ土壁

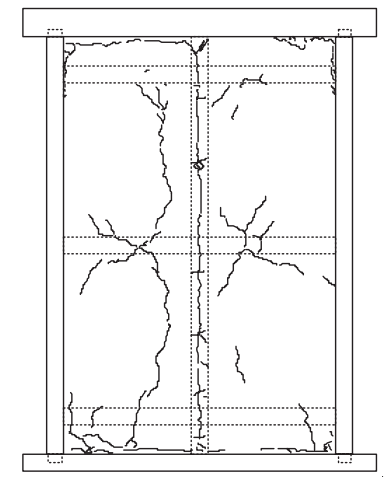

(b) 伝統的土壁
図 $111 / 17.5 \mathrm{rad}$. 加力終了後の表面ひび割れ

\section{5 超音波伝播時間測定を用いた損傷推定}

土壁の内部損傷状況を推定することを目的に、超音波伝播時間の 測定を行った。測定に用いたのは図 12 (a)に示すようにコンクリー 卜の非破壊試験に一般的に使われる測定器 (CNS FARNELL Pundit7) である。測定用のセンサーは、37kHz、50 ( $\phi) \times 50 \mathrm{~mm}(\mathrm{~L})$ の送受信機 各 1 個を、土壁の両側に密着させ (対面法)、その間の伝播時間を測 定した。また、壁の両側の同位置に送受信機を配置するため、図 12 (b) に示寸トランスポインタ(日本ヒルティ PX10)を用いた。トラ ンスポインタは、片方のトランスミッターから放出される磁場を、 土壁を挟んでもう片方の側にあるレシーバーが検知することで同位 置に誘導し、 $\pm 2 \mathrm{~mm}$ の精度で位置合わせをすることができる。この トランスポインタに超音波測定器のセンサー部を組み込み、土壁の 両側で正確に位置合せを行ったうえで測定を実施した。

プレファブ土壁の測定は、図 13 (a) に示すように、各ユニットで 16 点ずつ計 192 点測定した。測定は試験前 (非損傷状態) と、1/50 rad. 加力後、1/17. $5 \mathrm{rad}$. 加力後 (終局) に全測定点について 2 秒間隔で 1 分間の計測を行い、その平均值を測定值とした。測定結果の分析に は加力後の測定結果を非損傷状態の測定結果で割った伝播時間増加 率を用いた。(式 (1))

$$
\text { 伝播時間増加率 }(\%)=\frac{\text { 加力後伝播時間 }(\mu \mathrm{sec})}{\text { 非損傷時伝播時間 }(\mu \mathrm{sec})}
$$

乾燥した壁土は損傷が進むと内部の空隙やクラックが増加し、伝 播時間が増大寸ると考えられる。よってこの伝播時間の増加率が測 定位置の損傷度を示寸指標となると考えられる。図 14 はプレファブ 土壁の各測定点における伝播時間増加率を白黒の濃淡でマップ化し た図である。1/50rad. 加力後の結果ではいくつかのユニットの隅角 部に損傷が見られる。1/17. $5 \mathrm{rad}$. 加力後の結果ではほぼ全てのユニ ットの隅角部に損傷が見られた。プレファブ土壁は各ユニットで、 ほぼ均等にかつ同一のタイミングで損傷が発生していたことが分か る。

伝統的土壁についても同様に、図 13 (b) に示す 192 点の測定を行 った。加力前 (非損傷状態)の測定では全ての測定点で值を得ること が出来たが、1/120rad. 加力終了後の測定では全測定点のうち 150 点が測定不可となった (図中

プレファブ土壁の超音波伝播時間の上昇のメカニズムは、主応力 である対角線方向圧縮力による壁土の圧縮せん断すべりであるのに 対し、伝統的土壁では土壁内部の貫の動きにより、壁土の表面層と 内部層の間にせん断力が生じ、壁土内部に剥離層を形成したため超 音波の伝播が不可となったと考えられる。一方で、図 6(c) の荷重変 形関係からは、この時 $(1 / 120 \mathrm{rad}$. 加振終了時)の伝統的土壁の剛性、 耐力は低下していないことが確認できる。よって伝統的土壁におけ る剥離層の発生はせん断耐力の低下に及ぼす影響は少なく、このこ とより伝統的土壁の損傷推定に超音波測定を用いることは困難であ ると言える。

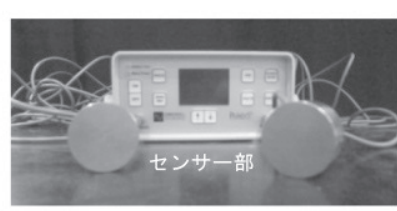

(a) 超音波測定器

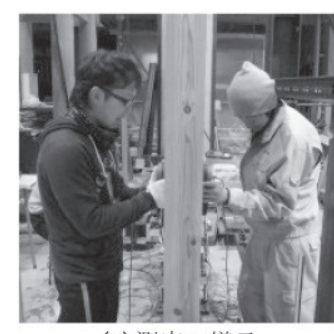

(c) 測定の様子

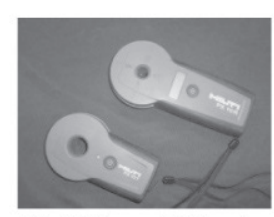

(b)トランスポインタ
図 12 土壁の超音波測定

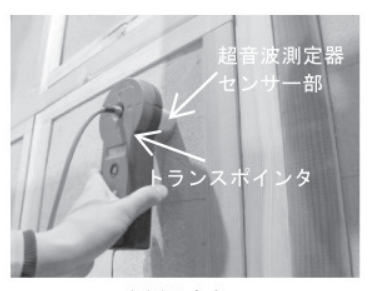

(d) 測定部

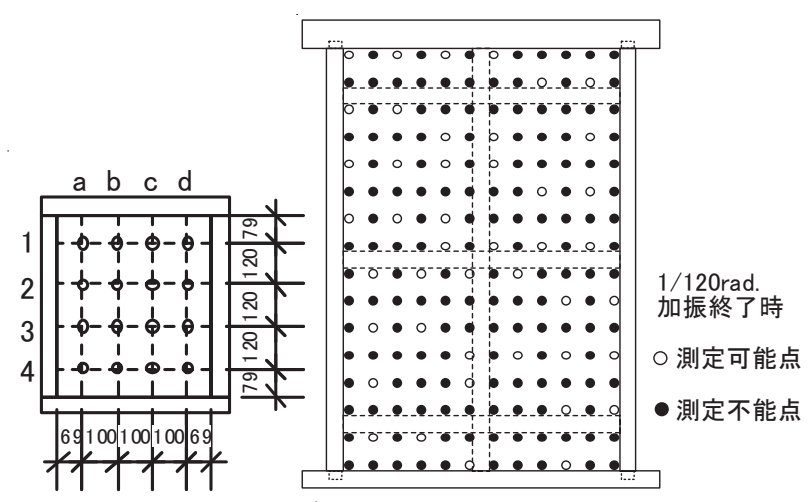

(a)プレファブ土壁

図 13 超音波測定位置 


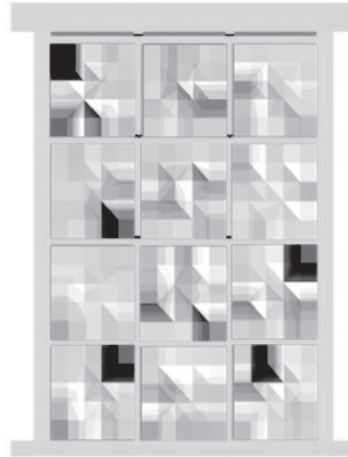

(a) $1 / 50 \mathrm{rad}$. 加振後

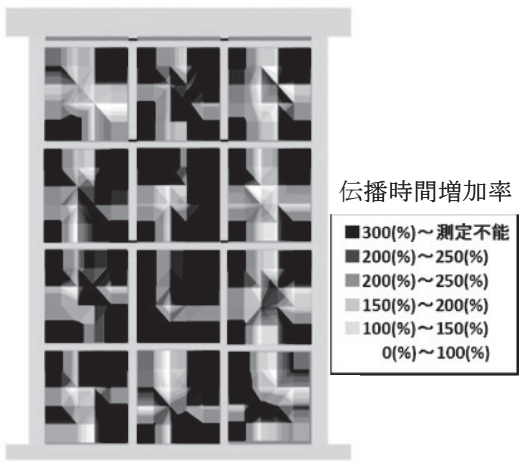

(b) $1 / 17.5 \mathrm{rad}$. (終局) 加振後
図 14 プレファブ土壁の超音波測定值増加率マップ

\section{3. プレファブ土壁の耐力特性の解析的検討}

\section{1 解析モデルの作成と実験結果との比較}

プレファブ土壁の耐力特性を解析的に検討する。まず、プレファ ブ土壁単体ユニットと、木軸フレーム十全面壁の状態の方立、横栈 を配置したフレーム (以下、木軸十方立・横栈)の、せん断力に対す る復元力特性を拡張 NCL モデル ${ }^{9)}$ を用いてそれぞれモデル化した。 木軸十方立・横栈の抵抗力は、柱ほぞの挿入部や方立・横栈の交点 部の摩擦及びめり込み抵抗と、ホールダウン金物のアンカーボルト による剛性等の合計であると考えられるが、解析を簡易化するため、 木軸十方立・横栈の静的加力試験結果から一括でモデル化した。表 4 に作成した解析モデル（拡張 NCL モデル) の各パラメータ值を示す。 図 15 は実験結果と作成した解析モデルの荷重変形関係の比較であ る。包絡線、固有ループ共に概ねよく模擬できていることが分かる。 これらの解析モデルを用いてプレファブ土壁の解析を行った。図 16 にプレファブ土壁の平面フレームによるモデル化図を示す。部材接 合部は全てピン接合とし、単体ユニットの復元力特性モデルは、各 横栈間のせん断変形に対して耐力を発揮するように配置し、木軸十 方立・横栈の復元力特性モデルは層間変形に対して耐力を発揮する ように配置した。また、各部材 (柱、梁、土台、方立、横栈)につい ては曲げ変形による影響を考慮するため、設計規準 ${ }^{100}$ にある平均的 な值を用いてヤング係数、せん断弾性係数を設定した。図 17 に全面 壁の実験結果と解析モデルの比較を示す。解析結果は実験結果の全 体的な特徴を概㱛良く捉えており、本解析モデルの妥当性を確認で きる。

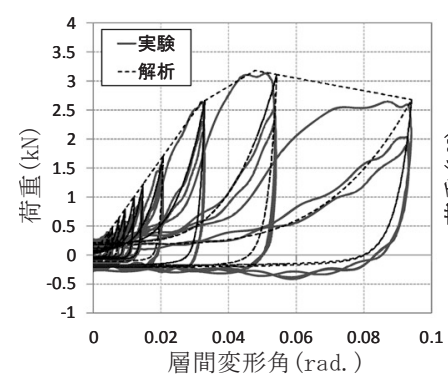

(a)プレファブ土壁単体ユニット

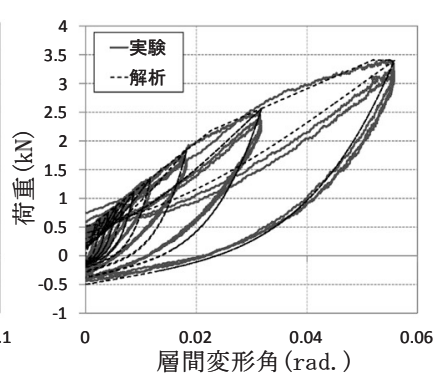

(b) 木軸十方立・横栈
図 15 復元力特性のモデル化

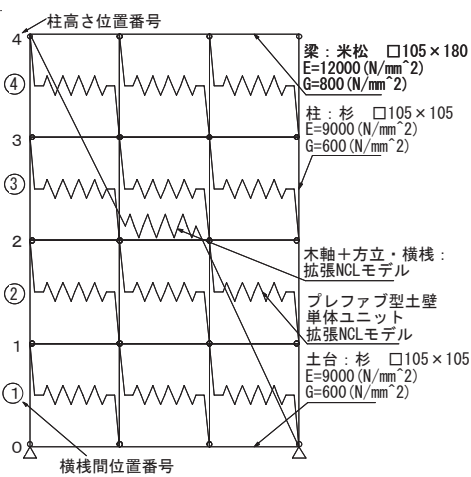

表 4 拡張 NCL モデルの パラメータ設定值

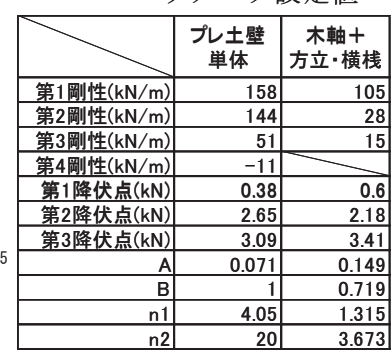

図 16 全面壁のモデル化図

拡張 NCL モデルの固有ループ式と各パラメータ

載荷ループ式 $\quad \mathrm{L}_{1}(\mathrm{x})=\left(B \cdot|x|^{n 1}+1-B\right) \cdot x \mp A\left(x^{4}-1\right) \quad$ （2）

除荷ループ式 $\quad \mathrm{L}_{2}(\mathrm{x})=\left(B \cdot|x|^{n 2}+1-B\right) \cdot x \pm A\left(x^{4}-1\right)$

$\mathrm{A}$ : 荷重切片值 $\mathrm{B}$ : スリップ勾配 $\mathrm{n} 1, \mathrm{n} 2$ : ループ曲線形状

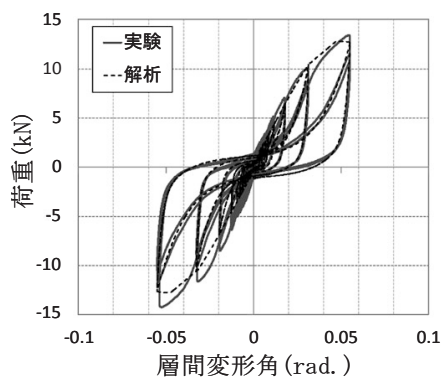

図 17 全面壁の荷重変形関係比較

\section{2 開口の異なるプレファブ土壁の耐カ特性}

プレファブ土壁は単体ユニットの配置によって、様々な開口形式 に対応することが可能である。ここでは開口形状の違いがプレファ ブ土壁の耐力特性に与える影響を解析的に検討する。検討する解析 モデルは 4. の振動台実験の試験体として用いる、図 18 の 4 種類と した。PM12 は全面壁であり、試験体番号の数字が単体ユニットの配 置数となっている。それぞれの開口形状の壁について、3.1 で示し た方法で平面フレームモデルを作成し、一方向の変位増分による解 析を行い、各モデルの荷重一変位曲線を得た。なお、方立・横栈分 の抵抗力については PM10, PM8, PM3 では減少するものと考えられる が、ここでは全て 3.1 の木軸十方立・横栈のモデルを用いた。図 19 に各モデルの解析結果と、全面壁、木軸フレーム、木軸十方立・横 栈の実験結果の包絡線を示す。垂れ壁形式の PM3 は 1/50rad.までは 木軸十方立・横栈と同等の耐力值で推移しており、プレファブ土壁 による耐力増加が大変形角時からであることが分かる。

表 5 は各モデルの荷重変形関係から設計用特性值の評価を行った 結果である。大きな開口を持つモデルの方が降伏変形角が大きく、 塑性率が低いため、構造特性係数 Ds が高い值となる。しかし、いず れの試験体も短期許容せん断耐力は $1 / 120$ (rad.) 時の耐力にて決定 される。

図 20 は各解析モデルの最大変形角 $(1 / 17.5 \mathrm{rad}$.$) 時の柱の傾き$ を示した図である。柱高さ位置番号は図 16、図 18 に対応している。 PM3 は中央辺りで外側に膨らんだ形状となっている。PM3 は試験体上 
部にのみ単体ユニットが配置されているため、柱上部の剛性が相対 的に高くなり、これにより下部の柱の曲げ変形が大きくなったもの と考えられる。図 21 は各解析モデルの最大変形角時の横栈間の変形 角を比較した図である。横栈間位置番号は図 16 に対応している。 PM12 については各位置の変形角が全体の層間変形角とほぼ同等で ある。PM10、PM8 では開口のある位置の変形角が全体の層間変形角 を上回っており、この部分に配置されている開口部横の単体ユニッ トに損傷が集中することを示している。PM3 は単体ユニットが配置 されていない試験体下部の柱の曲げ変形が大きくなるため、単体ユ ニットがある(4)部の変形角は相対的に小さい。

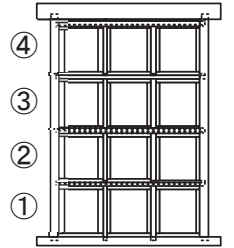

(a) PM12

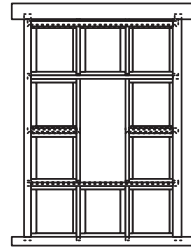

(b) PM10

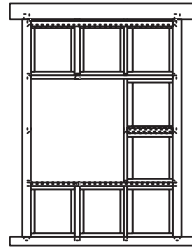

(c) PM8

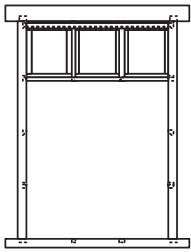

(d) PM3
図 18 開口の異なるプレファブ土壁

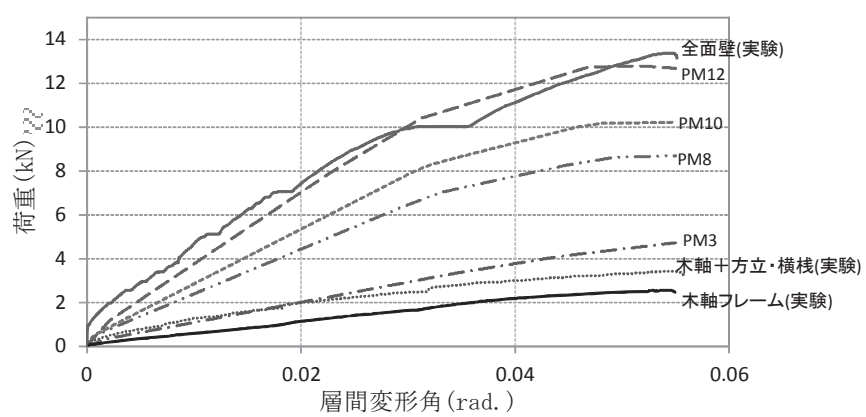

図 19 荷重変形関係の比較

表 5 設計用特性值評価結果一覧

\begin{tabular}{|c|c|c|c|c|}
\hline 特性値 & PM12 & PM10 & PM8 & PM3 \\
\hline 最大耐力Pmax(kN) & 12.78 & 10.21 & 8.68 & 4.71 \\
\hline 最大耐力時変形角Rmax(rad) & 0.0520 & 0.0550 & 0.0550 & 0.0550 \\
\hline 降伏耐力Py(kN) & 9.23 & 7.97 & 6.54 & 3.30 \\
\hline 降伏変形角Ry(rad) & 0.0273 & 0.0306 & 0.0305 & 0.0342 \\
\hline 終局耐力Pu(kN) & 12.51 & 9.99 & 8.51 & 4.61 \\
\hline 終局変形角Ru(rad) & 0.0550 & 0.0550 & 0.0550 & 0.0550 \\
\hline 降伏点変形角Rv(rad) & 0.0370 & 0.0384 & 0.0397 & 0.0478 \\
\hline 剛性(KN/rad) & 338 & 260 & 214 & 96 \\
\hline 塑性率 $\mu$ & 1.49 & 1.43 & 1.39 & 1.15 \\
\hline 構造特性係数Ds & 0.71 & 0.73 & 0.75 & 0.88 \\
\hline $\mathrm{Pu} \cdot(0.2 / \mathrm{Ds})(\mathrm{kN})$ & 3.52 & 2.73 & 2.26 & 1.05 \\
\hline $2 / 3 P \max (k N)$ & 8.52 & 6.81 & 5.79 & 3.14 \\
\hline 1/120rad.時の耐力(kN) & 3.19 & 2.41 & 2.03 & 0.92 \\
\hline 短期許容せん断耐力(kN) & 3.19 & 2.41 & 2.03 & 0.92 \\
\hline 壁倍率 $(1 \mathrm{~m}$ 当たり) & 0.9 & 0.7 & 0.6 & 0.3 \\
\hline
\end{tabular}

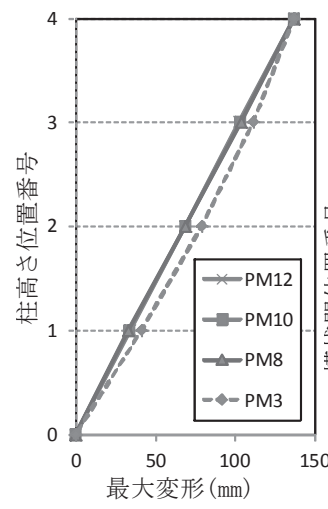

図 20 柱の傾き

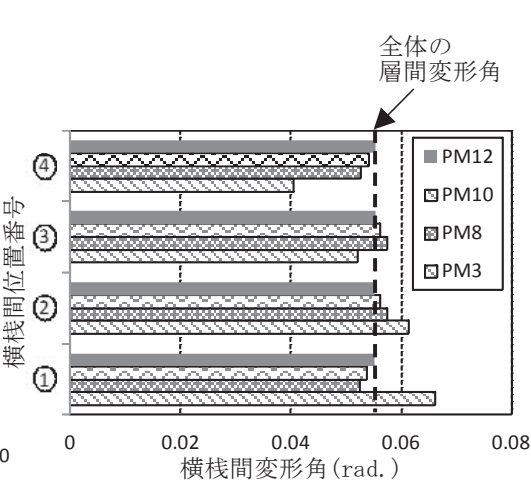

図 21 横栈間の変形角の比較

\section{4. プレファブ土壁の振動台加振実験と解析的検討}

\section{1 試験概要}

図 18 に示した開口の異なる 4 種類のプレファブ土壁を試験体と して振動台による加振実験を行った。試験システムを図 22 に示す。 本試験システムでは平面フレームの耐力壁を用いて振動台実験を行 う。試験体上部の鉄骨梁は錘との合計で $9.6 \mathrm{kN}$ の重量となっている。 鉄骨梁は面外変形拘束用フレームとクランク機構により繋がれてお り、錘の慣性力が試験体の面内せん断方向のみに作用する仕組みと なっている。試験は表 6 に示すように兵庫県南部地震神戸海洋気象 台観測波南北成分 (以下、神戸波)の最大速度をそれぞれ Lv1、Lv2、 原波に基準化し順に加振を行った。また各加振の前後には常時微動 測定 $(300 \mathrm{sec})$ を実施した。

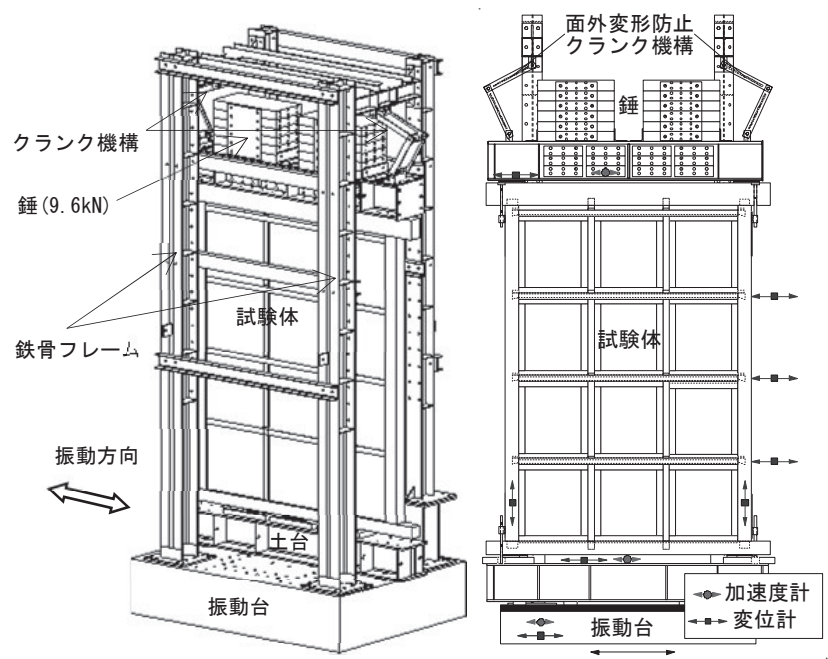

図 22 振動台実験システム

表 6 振動台実験加振スケジュール

\begin{tabular}{|l|}
\hline 試験入力波 \\
\hline \hline 神戸波 Lv1(最大速度 25kine、最大加速度 224gal) \\
\hline 神戸波 Lv2 (最大速度 50ine、最大加速度 448gal) \\
\hline 神戸波 原波 (最大速度 91kine、最大加速度 818gal) \\
\hline 各加振の前後に常時微動測定を実施 \\
\hline
\end{tabular}

\section{2 常時微動測定による等価剛性・減衰定数の変化}

地震波加振の前後に実施した常時微動の測定結果を用いて等価剛 性及び減衰定数の同定を行った。振動台上と試験体頂部で測定した 加速度時刻歴を高速フーリエ変換により処理し応答倍率曲線を求め た。高速フーリエ変換は、時刻歴データを 16384 点ずつの小サンプ ルに分割し、50\%のオーバーラップによるアンサンブル平均で重ね 合わせ、スペクトルの平滑化には Parzen ウィンドウのバンド幅 $0.05 \mathrm{~Hz}$ を用いた。この応答倍率曲線に理論曲線を最小二乗法により 近似し、固有振動数及び減衰定数を同定した（カーブフィット法）。 更に、同定した固有振動数、減衰定数と試験体上部の重量の関係か ら下式(4)を用いて等価剛性 Keq を推定した。

$$
K e q=\frac{4 \pi^{2} \times m}{T d^{2} \times\left(1-h^{2}\right)}
$$

$m$ : 試験体上部質量 $(\mathrm{t}) \quad T d$ : 減衰固有周期 $(\mathrm{sec}) \quad h$ : 減衰定数 $(\%)$

図 23 に測定時にける試験体の最大経験変形角と等価剛性Keq の関 係を示す。地震波加振前 (最大経験変形角 0 ) の状態では、開口部が 
大きい試験体ほど等価剛性は低い。加振が進み最大経験変形角が増 加すると等価剛性は低下していくが、大きな開口を持つ試験体 (PM3、 PM8) は、開口が小さい試験体 (PM12、PM10) に比べて等価剛性の低下 が少ない。これは、3.2 の解析で示したように、開口部を持つ試験 体は、開口部横の柱の曲げ変形が大きくなり、相対的に開口部横以 外の単体ユニットの損傷が少なくなるためであると考えられる。

図 24 に減衰定数の変化を示す。加振前では開口率が低く剛性の高 い試験体の方が、減衰定数が低い傾向にある。また、最大経験変形 角が増加し試験体の損傷が進むにつれ減衰定数は上昇する傾向にあ ることが分かる。

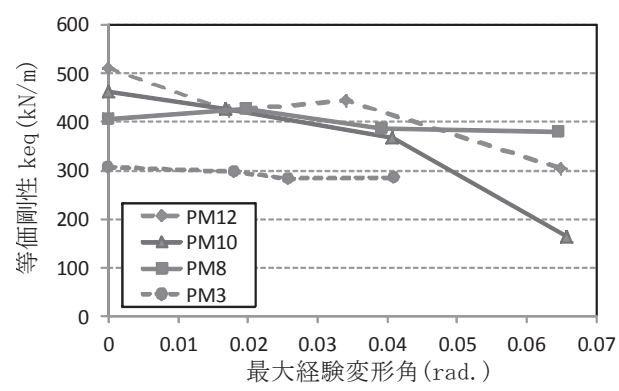

図 23 等価剛性の変化

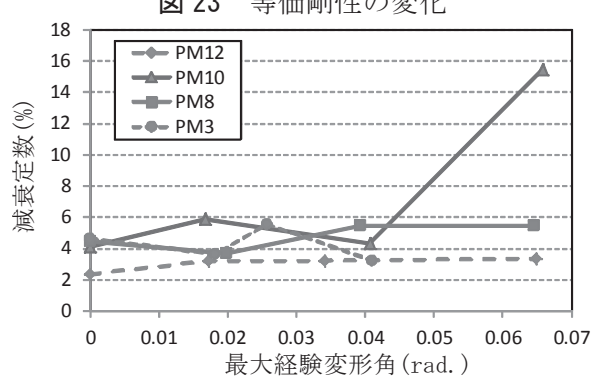

図 24 減衰定数の変化

\section{3 地震波加振結果と解析結果との比較}

地震波加振による実験結果と解析モデルによる時刻歴応答解析結 果との比較をおこなう。前章で作成した各試験体の平面フレーム解 析モデルの上部に、試験で載荷したのと同重量の荷重を作用させる。 数值積分は Newmark $の \beta$ 法 $(\beta=0.25)$ を用い、減衰マトリックスは、 構造全体の剛性に対して瞬間剛性比例型で $5 \%$ となるように設定し た。解析の入力值には実験時に振動台上で計測した加速度記録を用 いて応答計算を行った。

図 25 は各試験体の地震波加振結果と、その解析結果の荷重変形関 係である。全加振を重祆て示しており、実線が実験結果で破線が解 析結果である。各試験体とも実験結果と解析結果の履歴形状及び最 大応答值は概㸚対応しているが、解析結果より実験結果の方が、特 に大変形領域において耐力が小さくなる傾向がみられる。これは単 体ユニットと木軸の間の隙が、繰り返しの加振により増大寸る現象 を実験時に確認しておりこれにより剛性が低下したことと、3.2 で 説明したように PM10, PM8, PM3 のモデルについては、方立・横栈の減 少分を解析モデルに反映していないことによる影響であると考えら れる。

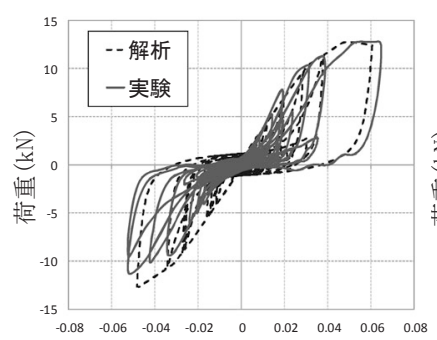

層間変形角 $(\mathrm{rad}$.

(a) PM12

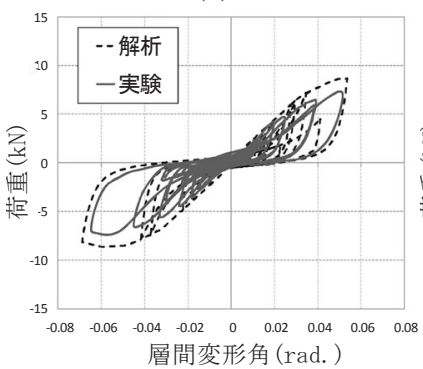

(c) PM8

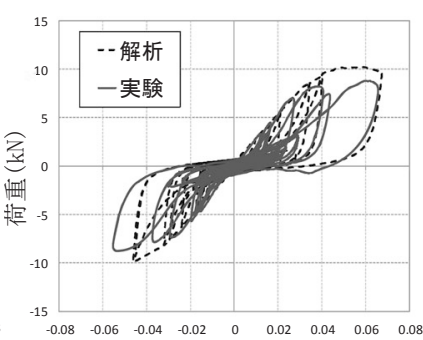

層間変形角 (rad.)

(b) PM10

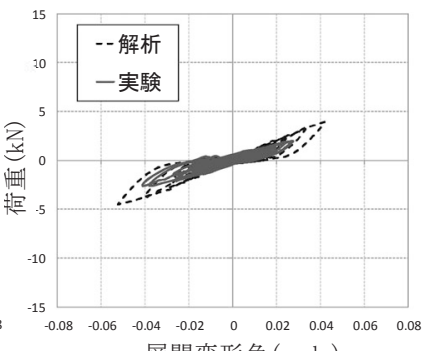

間変形角 (rad. )

(d) PM3
図 25 振動台実験結果と解析結果の比較

\section{4 超音波伝播時間測定を用いた損傷推定}

各試験体の地震波加振による内部損傷状況を推定するため、超音 波伝播時間測定による損傷推定を行った。測定方法は 2.5 で示した 通りである。図 26 は地震波加振前の測定值と神戸波原波後の測定値 を用いてその増加率をマップ化した図である。PM12 では各ユニット の隅角部の損傷が全体的に分布しているのに対し、PM10、PM8 では 開口部横の損傷が大きいことが分かる。特に、PM8 の試験体では開 口部右横のユニットの損傷に比べて、開口部上下のユニットの損傷 が大幅に少ないことが分かる。

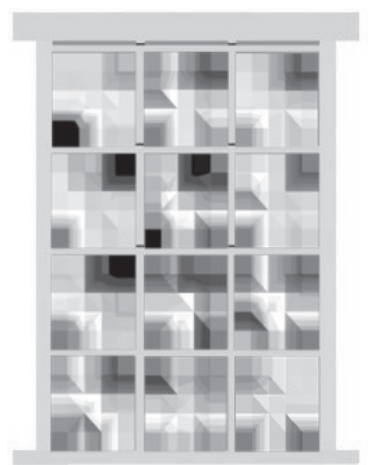

(a) PM12

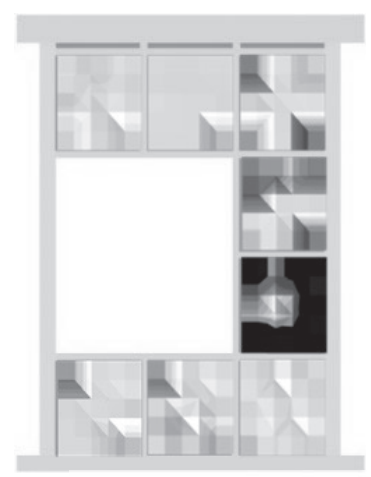

(c) PM8

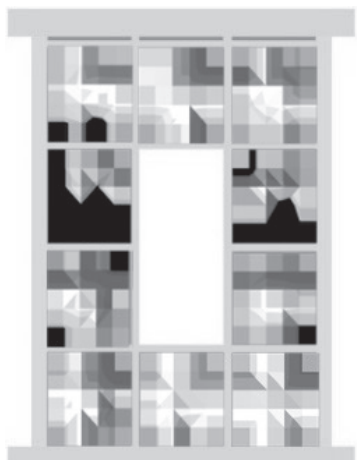

(b) PM10

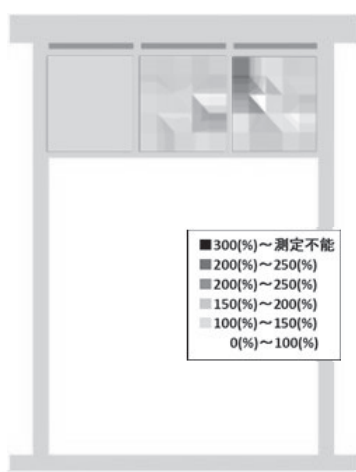

(d) PM3
図 26 プレファブ土壁の超音波測定值増加率マップ 
5. まとめ

本研究により得られた知見をまとめて以下に示す。

（1）プレファブ土壁は単体ユニットの集合であり、その耐力特性は 伝統的土壁に比心゙非常に単純な耐力発現機構を有す。単体ユニ ットのせん断耐力の大部分は壁土の対角線圧縮抵抗によるもの であると考えられる。プレファブ土壁は伝統的土壁に比べ、経 験変形角の進行に伴う保有エネルギーの低下が少なく、地震等 の繰り返しの加振に対するエネルギー吸収能力の低下が少ない と考えられる。一方でプレファブ土壁は伝統的土壁と最大耐力 が同程度であるにもかかわらず、初期剛性が低いため、現行の 壁倍率評価法に則った評価においては低い許容耐力値となる。 プレファブ土壁の初期剛性は木軸フレームと単体ユニット間の 接合部の剛性に依存しており、既報 ${ }^{1)}$ では木ダボ挿入により、 既報 ${ }^{2)}$ ではビスによる留めつけを行うことで伝統的土壁と同等 以上の初期剛性を確保することが可能であることを確認してい る。施工の簡易性と金物使用の減少を両立寸る、留めつけ方法 の提案については今後の課題としたい。

（2）土壁の超音波伝播時間の測定による損傷評価は、プレファブ土 壁の単体ユニットの損傷推定に有効である。実務的には、プレ ファブ土壁を適用した建物が地震を経験した際に超音波測定を 実施し、損傷の激しい単体ユニットを見つけて交換することで、 建物の耐震性能を復旧するといった運用方法が期待できる。一 方で、内部に貫を有する伝統的土壁では、土壁内部の剥離によ り早期に測定不可となるため、損傷度の推定に本手法を用いる のは現状では困難である。

（3）プレファブ土壁の破壊性状は全て単体ユニット隅角部の圧縮破 壞である。全面壁の場合は各単体ユニットに均等に分散して破 壊が生じるが、開口を持つ壁の場合は、開口部横の単体ユニッ トに損傷が集中する傾向にある。

（4）プレファブ土壁は単体ユニットの耐力特性を把握し、平面フレ 一ムによる解析を行うことで、全面壁及び各種の開口を有する 壁の耐力特性を把握することが可能である。また、単体ユニッ トの復元力特性に拡張 NCL モデルを用いて時刻歴応答解析を行 うことで、地震時の応答を概ね予測できる。

（5）伝統木造建築等の保存改修に際しても本プレファブ土壁の適用 は、従来の建築様式・構法の変更を伴わず、かつ鞋性型の軸組 構法の特性を保持できるものとして考えられる。

\section{謝辞}

本研究は平成 22 年度京都大学生存圈ミッション研究「自然素材活 用型住宅における耐力要素の動的構造特性の検証実験」、平成 23 年 度京都大学生存圈ミッション研究「自然素材活用型住宅における耐 力要素の改良と動的・静的構造特性の比較検証」の助成を受けて実 施いたしました。

\section{付録 損傷限界・安全限界エネルギー変化率の説明 ${ }^{11)}$}

試験体の繰り返し加振に対する劣化度を評価する指標として、損傷限界 • 安全限界エネルギー変化率を用いた。付図 1 に示すように加力試験結果の荷 重変形関係において 1/120 rad. を損傷限界変形角、1/30 rad. を安全限界変形 角と定める。次に原点を通る横軸と全加振の包絡線及び損傷限界変形角線で 囲まれる面積を算出し、これを健全な状態の試験体が損傷限界までに吸収で
きる保有エネルギー量として全損傷限界エネルギー（Ey）とする。同様に原点 を通る横軸と全加振の包絡線及び安全限界変形角線で囲まれる面積を全安全 限界エネルギー $(\mathrm{Eu})$ とする。これ対し最大変形角の異なる各加振の荷重変形 関係の包絡線についても同様に加振毎の損傷限界エネルギー(Ey') 安全限界 エネルギー (Eu') を求める。これらの比を算出することで損傷限界エネルギ 一変化率 $\left(\mathrm{Ey}^{\prime} / \mathrm{Ey}\right.$ )、安全限界エネルギー変化率 (Eu'/Eu) とした。各加振の 最大経験変形角と保有エネルギーの変化率との関係を示すことで、試験体の 繰り返し加力による劣化度を評価する指標とした。なお、各加振の保有エネ ルギーの算出において未経験の変形角については全加振の包絡線上を通るも のとして算出を行っている。

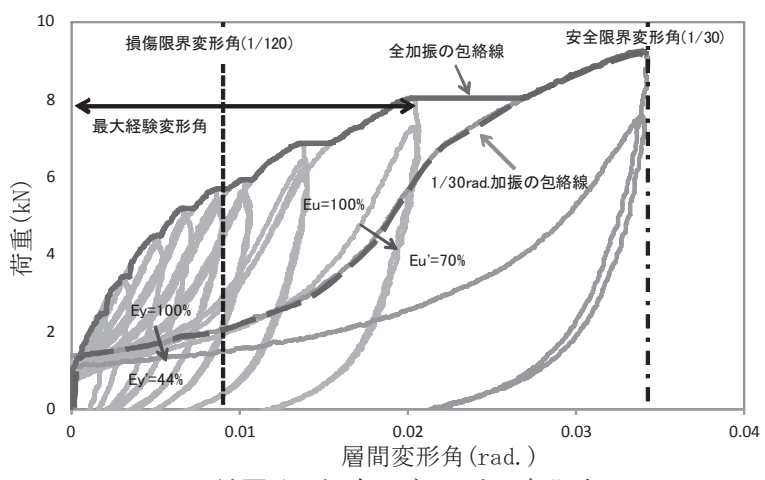

付図 1 保有エネルギー変化率

\section{参考文献}

1）小松 幸平, 片岡 靖夫, 森 拓郎他 5 名: 提案住宅のコンセプトと構造性能 の概要 自然素材活用型木造軸組み構造の開発 (その 1) (構造), 日本建 築学会技術報告集，第 14 巻, 第 28 号, pp. 447-452, 2008. 10

2）鄭 基浩, 北守 顕久, Hassel Ivon, 小松 幸平 : プレファブ型土壁の水平せ 几断性能の評価，日本建築学会技術報告集，第 16 巻,第 34 号, pp. 929-934, 2010. 10

3）村上 雅英, 景山 誠, 鈴木 有, 稲山 正弘 : 静的水平加力実験に基づく土壁 の而荷機構の解明 せん断破壊が先行しない土壁の力学挙動, 日本建築 学会構造系論文集, 第 582 号, pp. 103-108, 2004.08

4）山田 耕司, 清水 秀丸, 中治 弘行, 鈴木 祥之: 土塗り 小壁付き木造軸組而 力特性評価への数值解析の適用, 日本建築学会構造系論文集, 第 621 号, pp. 81-87, 2007. 11

5) 中尾 方人, 山崎 裕 : 数值解析による土塗り壁のせん断抵抗機構の検討, 日本建築学会構造系論文集, 第 74 巻, 第 636 号, pp. 331-338, 2009. 02

6）鄭 基浩, 北守 顕久, 小松 幸平, 脇田 健裕, 片岡 靖夫: 超音波伝播速度測 定による土塗壁の損傷評価, 日本建築学会技術報告集, 第 18 巻, 第 40 号, pp. 895-900, 2012. 10

7）日本住宅木材技術センター：土塗壁・面格子壁・落とし込み板壁の壁倍 率に係る技術解説書, 2004

8）（財）日本住宅・木材技術センター：木造の耐力壁及びその倍率性能評価 業務方法書, 2010

9）松永 裕樹, 宮津 裕次, 曽田 五月也：木造軸組耐力壁/非耐力壁の汎用モ デル化手法に関する研究, 日本建築学会構造系論文集, 第 74 巻, 第 639 号, pp. 889-896, 2009. 05

10）日本建築学会:木質構造設計規準 ・同解説一許容応力度・許容耐力設計法

11）綿引 誠, 大橋 好光, 塩沢 伸明: 木造軸組耐力壁及び実物大建物の微動測 定に関する実験的研究 その 2 壁要素の振動台実験, 日本建築学会大 会学術講演梗概集， C-1，pp. 445-446，2004.07

（2012年12月27日原稿受理，2013年 5 月15日採用決定） 